\title{
How to Create Evidence for the Integration of Local and Locoregional Treatments in Future Oncological Treatment Concepts?
}

\author{
Florian Lordick $^{\mathrm{a}} \quad$ Jens Ricke ${ }^{\mathrm{b}} \quad$ Konrad Mohnike $^{\mathrm{b}} \quad$ Ulrich Hacker $^{\mathrm{a}}$ \\ a University Cancer Center Leipzig (UCCL), University Clinic Leipzig, Leipzig, Germany \\ ${ }^{\mathrm{b}}$ Department of Radiology and Nuclear Medicine, University Clinic Magdeburg, Magdeburg, Germany
}

Keywords

Oligometastases - Colorectal cancer .

Renal cancer · Ovarian cancer · Ablation

\section{Summary}

Background: While local treatment using more innovative technologies is increasingly applied in contemporary treatment of advanced cancer, its impact on outcomes is not well understood. Methods: We reviewed the literature using PubMed and major oncology congress websites, and report here about the understanding of oligometastatic disease, about the role of primary tumor resection in metastatic disease, and about the value of cytoreduction and tumor ablation. Results: The Achilles' heel of local treatment is the current lack of evidence of its efficacy. When considering how this lack of knowledge can be overcome, we arrive at three suggestions: First, adequately powered clinical trials must be performed to allow for the proper assessment of differences in survival outcomes. Second, the effect of local treatment on the biological evolution of the disease needs to be studied; analysis of circulating tumor DNA may help to assess these effects. Third and foremost, patient-reported outcomes like quality of life, symptom control, and satisfaction with treatment should define when to use and when to omit local treatment. Conclusions: Innovative trial designs in future oncology research will be required for assessing the true value of local and locoregional therapy.
Schlüsselwörter

Oligometastasierung · Kolorektales Karzinom · Nierenzellkarzinom · Ovarialkarzinom · Ablation

\section{Zusammenfassung}

Hintergrund: Während lokale Tumorbehandlung mit innovativen Technologien einen zunehmenden Raum in der heutigen Therapie fortgeschrittener Tumorerkrankungen einnimmt, ist ihre Bedeutung für die Ergebnisverbesserung weiterhin schlecht definiert. Methoden: Wir führten eine Literatursichtung über PubMed und große OnkologieKongress-Websites durch und berichten über das derzeitige Verständnis der oligometastasierten Erkrankung, die Rolle der Primärtumorresektion bei metastasierter Erkrankung und über den Stellenwert von Zytoreduktion und Tumorablation. Ergebnisse: Die Achillesferse der Lokalbehandlung ist die derzeit mangelhafte Evidenz für ihre Wirksamkeit. In Überlegung, wie dieser Mangel beseitigt werden kann, unterbreiten wir drei Vorschläge: Erstens müssen ausreichend große klinische Studien durchgeführt werden, welche die saubere Erfassung lebenszeitbezogener Unterschiede erlauben. Zweitens müssen die Auswirkungen einer Lokalbehandlung auf die biologische Evolution der Erkrankung untersucht werden. Die Analyse zirkulierender Tumor-DNA könnte hilfreich sein, um diese Effekte zu verstehen. Drittens, besonders wichtig ist die Erfassung patientenberichteter Veränderungen im Bereich der Lebensqualität, Symptomkontrolle und Behandlungszufriedenheit. Diese Ergebnisse sollten den Weg weisen, in welcher Situation in Zukunft lokoregionale Behandlung angewendet und wann sie unterlassen werden sollte. Schlussfolgerung: Wir benötigen für die Onkologie von morgen innovative Studiendesigns, um den wahren Stellenwert lokaler und lokoregionaler Behandlungsverfahren zu bestimmen.

\section{KARGER \\ Fax +497614520714}

Information@Karger.com

www.karger.com (c) 2014 S. Karger GmbH, Freiburg

1662-6664/14/0304-0261\$39.50/0

Accessible online at:

www.karger.com/vim
Prof. Dr. med. Florian Lordick

Universitäres Krebszentrum Leipzig

Universitätsklinikum Leipzig

Liebigstraße 20, 04103 Leipzig, Germany

florian.lordick@medizin.uni-leipzig.de 


\section{Introduction}

Malignant tumors are staged according to the TNM system as published by the American Joint Committee of Cancer (AJCC) and the Union International Contre le Cancer (UICC) [1]. In the case of any distant metastasis, regardless of the amount and the overall tumor burden, the cancer is classified as stage IV. This does not take into account that metastases may be limited to certain sites (oligometastatic) in contrast to being spread around the entire body (diffuse).

\section{Oligometastases}

The concept of oligometastatic disease is an evolving disease status. Its first nomination dates back to the year 1995 [2]. There is no doubt that the knowledge of tumor biology was still much less advanced at this time point. However, the authors proposed the existence of a clinically significant state of oligometastasis. They hypothesized that in oligometastatic disease - despite the existence of distant metastases - locoregional treatment can achieve cure: 'An attractive consequence of the presence of a clinically significant oligometastatic state is that some patients so affected should be amenable to a curative therapeutic strategy'. Another very interesting statement in this first attempt to define 'oligometastases' is the following: 'As effective chemotherapy becomes more widely applicable, there should be another group of patients with oligometastases. These are patients who had widespread metastases that were mostly eradicated by systemic agents, the chemotherapy having failed to destroy those remaining because of the number of tumor cells, the presence of drugresistant cells, or the tumor foci being located in some pharmacologically privileged site'. What does this mean to us today, almost 20 years after the introduction of the oligometastatic state? First, we should critically revise our current understanding of stage IV cancer. The TNM classification induces an understanding of distinct tumor stages with separate phenotypes and a different prognosis. This is probably not the whole truth. It may be more appropriate to regard tumor spread as a multistep process reaching from very limited localized disease to truly systemic disease. The multiple phenotypes occurring in this multistep process are reaching from the one extreme to the other. This process could be more adequately called the 'metastatic cascade' (fig. 1). Recently published experimental data indicate that metastatic spread may take place as early as when the first premalignant precursors of an epithelial cancer develop. This has been demonstrated in an experimental pancreatic cancer model [3]. Multiple mechanisms are involved in the shift from localized disease to systemic disease, like evasion of tumor cells, survival of cancer cells in the circulation, seeding and invasion in the periphery, angiogenesis, and immune escape $[4,5]$. Heterogeneity is another important emerging process that goes along with tumor

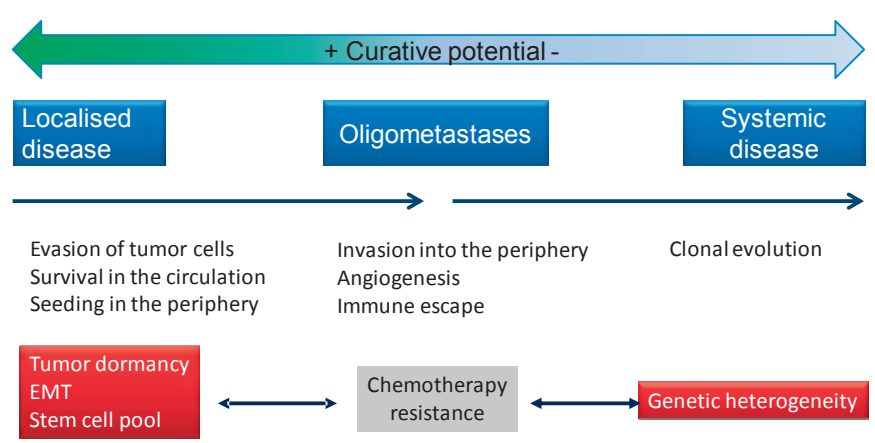

Fig. 1. The metastatic cascade: the continuum reaching from localized disease to oligometastases to systemic disease can be viewed as a multistep process involving multiple biologic mechanisms. Chemotherapy resistance is caused by different mechanisms (EMT = Epithelial-mesenchymal transition).

evolution $[6,7]$. The understanding of a 'metastatic cascade' matches with our experience that not all localized cancers are cured with local treatment alone while many presumably localized cancers relapse with distant metastases and need additional (adjuvant) chemotherapy in order to fight micrometastatic disease from the beginning. Likewise, some cancers with overt macroscopic distant metastases benefit from local treatment and may even be cured if resection, radiation, or ablation techniques are applied, with or without chemotherapy. The effectiveness of chemotherapy is hampered by tumor dormancy, epithelial-mesenchymal transition (EMT) and stemcellness (which may in part be addressed and overcome in the future by new drugs that are currently being developed), but is also caused by clonal evolution and increasing heterogeneity in disseminated stages (fig. 1).

At present, it is one of the most delicate tasks in clinical oncology to decide when local treatment in metastatic stages makes sense and is indicated. For this reason, we should direct our focus toward methods and markers that help distinguish oligometastatic disease stages from advanced tumor spread. Investigations of the prevalence, mechanism of occurrence, and position in the metastatic cascade, as well as the determination of molecular markers to distinguish oligometastatic from polymetastatic disease, are ongoing [5]. The importance of the oligometastatic state will be dependent on the size of the group of patients for whom it offers curative prospects. Although the notion of there being some patients with limited metastases is recognized, it is thought to be quite uncommon. What is important in oligometastasis is the recognition that it is not just a stochastic oddity but rather based on a state of limited metastatic capacity and a characteristic of many tumors during their clinical evolution. Most importantly, while efforts are being made to determine its extent, recognition of the existence and implications of a state of oligometastasis is necessary to invite active clinical investigation of new and potentially curative therapeutic strategies [2]. 


\section{Resection of the Primary Tumor}

Most patients who die of cancer do so because of metastatic disease, and therefore removal of the primary tumor in patients who already have evidence of metastasis seems illogical, at least in the absence of symptoms caused by the primary tumor. Many thoughtful oncologists have asked, 'What is the point of closing the barn door once the horse has bolted?', in the belief that subjecting patients with incurable disease to the risks involved in unnecessary surgery is a poor medical decision [8].

\section{Experience from Renal Cancer}

A crucial question is whether resection of the primary tumor confers a better prognosis. The only disease where this has been studied in randomized controlled trials is metastatic renal cell cancer $[9,10]$. The larger of the two studies showed that the median survival of 120 eligible patients assigned to surgery followed by interferon was 11.1 months, while among the 121 eligible patients assigned to interferon alone it was 8.1 months $(p=0.05)$. The difference in median survival between the two groups was independent of performance status, metastatic site, and the presence or absence of a measurable metastatic lesion [9]. The smaller of the two studies that was recruited by the European Organization for Research and Treatment of Cancer (EORTC) Genitourinary Group confirmed these results [10]. In conclusion, resection of the primary followed by systemic therapy resulted in longer survival among patients with metastatic renal cell cancer compared to systemic therapy alone. The reasons for this observation are largely unknown.

\section{Experience from Colorectal Cancer}

Can the observations from renal cell cancer be transferred to metastatic colorectal cancer? Data from the Surveillance, Epidemiology and End Results (SEER) data registry of the National Cancer Institute indicate a better overall survival (OS) after primary tumor resection compared with a conservative strategy [11]. The authors state that 'the proportion of patients undergoing resection depends on patient age and race and the anatomical location of the primary tumor. The degree to which case selection explains the treatment and survival differences observed is not known'. Clearly, more detailed information from prospective trials is warranted.

The Dutch Colorectal Cancer Group analyzed retrospectively the outcome of stage IV colorectal cancer patients with or without resection of the primary tumor treated in the phase III CAIRO and CAIRO-2 studies [12]. In these two studies, 258 and 289 patients had undergone a primary tumor resection, and 141 and 159 patients had not. In the CAIRO study, a significantly better median OS and progression-free survival (PFS) were observed for the resection compared to the nonresection group, with 16.7 vs. 11.4 months $(\mathrm{p}<0.0001$; hazard ratio (HR) 0.61 ), and 6.7 vs. 5.9 months ( $\mathrm{p}=0.004$; HR 0.74), respectively. In the CAIRO-2 study, median OS and PFS were also significantly better for the resection compared to the nonresection group, with 20.7 vs. 13.4 months $(\mathrm{p}<0.0001$; HR 0.65$)$ and 10.5 vs. 7.8 months ( $\mathrm{p}=0.014$; HR 0.78 ), respectively. These differences remained significant in multivariate analyses. Although this publication dealt with stage IV colorectal cancer, it did not specifically analyze the situation of synchronous metastases. This is the strength of a recent French publication from the Fédération Francophone de Cancérologie Digestive (FFCD) 96-01 study [13]. Among the 294 patients with nonresectable colorectal metastases enrolled in the FFCD 96-01 phase III trial which compared different first-line single-agent chemotherapy regimens, 216 (73\%) patients presented with synchronous metastases at study entry and constituted the study population. Potential baseline prognostic variables including prior primary tumor resection were assessed by univariate and multivariate Cox analyses. Among the 216 patients with stage IV colorectal cancer, 156 (72\%) patients had undergone resection of their primary tumor prior to study entry. The resection and non-resection groups did not differ in terms of baseline characteristics except for primary tumor location: rectal cancers were more often not resected: 14 versus $35 \%$ ( $\mathrm{p}=$ 0.0006). In a multivariate analysis, resection of the primary was the strongest independent prognostic factor for PFS (HR 0.5; $95 \%$ confidence interval (CI) $0.4-0.8 ; \mathrm{p}=0.0002)$ and OS (HR 0.4; CI 0.3-0.6; $\mathrm{p}<0.0001)$. Both median PFS (5.1 (4.6-5.6) versus 2.9 (2.2-4.1) months; $\mathrm{p}=0.001)$ and OS (16.3 (13.7-19.2) versus $9.6(7.4-12.5) ; \mathrm{p}<0.0001)$ were significantly higher in the resection group. The authors conclude that 'resection of the primary tumor may be associated with longer PFS and OS in patients with stage IV colorectal cancer starting first-line, single-agent chemotherapy'. In conclusion, the Dutch and the French retrospective analyses from prospective randomized trials support the hypothesis that resection of the primary tumor in the case of distant metastases may improve PFS and OS. The reason for this potential difference is unknown. This clinical research question merits prospective investigation.

For the situation of synchronous metastatic colorectal cancer, two randomized controlled trials with a comparable design are currently recruiting patients in Europe: SYNCHRONOUS is recruiting patients in Germany while CAIRO-4 is active in the Netherlands [14].

The published data indicate that at present the severity of symptoms should determine the strategy in metastatic colorectal cancer. If severe symptoms result from the primary tumor, local treatment (colostomy, radiation, stenting, or resection) is usually administered upfront. The choice of local treatment is tailored to the individual needs. In patients without symptoms from the primary tumor or with far advanced metastatic disease or with severe symptoms from metastatic disease, primary systemic treatment should be given first. Figure 2 illustrates the strategy followed at the University Cancer Center of Leipzig. This practical algorithm may reflect one preferred strategy in cancer centers in Europe. 


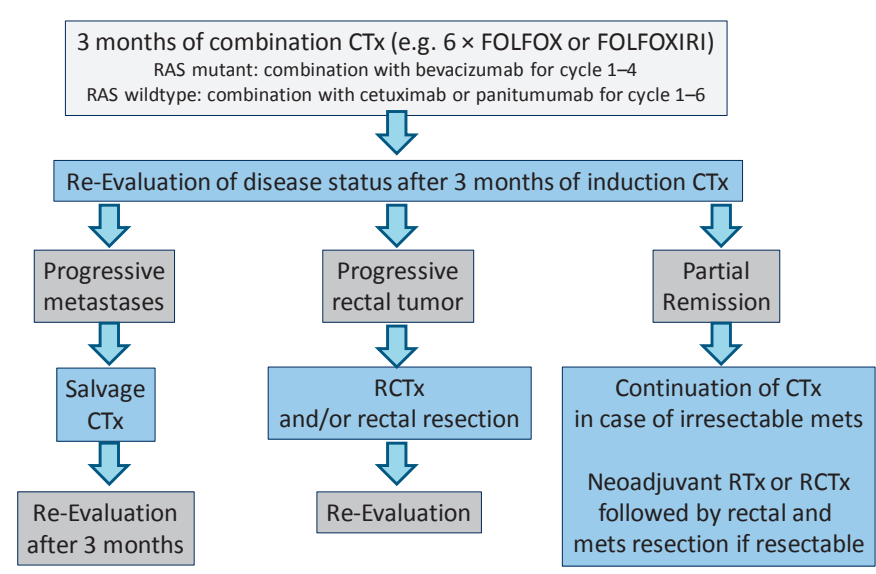

Fig. 2. Treatment algorithm of synchronous metastatic colorectal cancer at the University Cancer Center Leipzig (UCCL) (CTx = Chemotherapy; mets $=$ metastases $; \mathrm{RCTx}=$ radiochemotherapy; $\mathrm{RTx}=$ radiotherapy $)$.

\section{Cytoreduction and Ablation of Metastases}

The macroscopically visible parts of cancer can be seen as being only the tip of the iceberg [15]. From this perspective, it seems unlikely that any local destruction technique may substantially improve the prognosis of patients with metastatic disease.

\section{Experience from Epithelial Ovarian Cancer}

However, in some diseases, especially in advanced epithelial ovarian cancer, a debulking strategy is regarded as standard of care, at least when a macroscopically near-tumor-free status can be achieved [16]. Surgical debulking should be generally followed by systemic chemotherapy in order to postpone progression. In recent years, the concept of neoadjuvant chemotherapy and interval debulking has been studied as an emerging concept. It may help to achieve the goal of optimal surgical cytoreduction in more advanced epithelial ovarian cancer [17] Neoadjuvant chemotherapy should not be an easy way out, but is in some patients with stage IIIc or IV ovarian cancer a better alternative treatment option than primary debulking [18].

One can argue that surgical cytoreduction in ovarian cancer is not a blueprint for other malignant diseases. Although often diagnosed in advanced stages, ovarian cancer has a tendency to limit itself to the peritoneal cavity for quite a long time which makes it a candidate for locoregional interventions, including intraperitoneal chemotherapy [19]. However, recent results have shown that patients with malignant diseases of gastrointestinal origin may also benefit from peritonectomy which is often combined with hyperthermic intraperitoneal chemotherapy (HIPEC) [20]. This is particularly true for mucinous appendiceal cancer (for which no effective systemic chemotherapy is available), for colorectal cancer with predominant peritoneal metastases and a peritoneal carcinomatosis index (PCI) of less than 21, and - with much more reservation - for gastric cancer with peritoneal metas- tases as long as the PCI does not exceed 8-10. Due to the high prevalence of hematogenous metastases and the existence of relatively active drugs, peritoneal cytoreduction and HIPEC should generally be combined with systemic chemotherapy in gastrointestinal cancers.

\section{Experience from Gastrointestinal Cancer}

The value of locoregional treatment has also been investigated in malignant diseases with hematogenous spread. This is particularly true for colorectal cancer in which the splanchnic drainage of tumor cells goes via the portal vein to the liver [21]. The liver acts as a first filter. Tumor cells seed there and often remain there without further spread to other organs.

Experience with liver surgery in colorectal cancer has shown that superior outcomes can be achieved with liver resections [22]. Resections in metastatic disease can or should be combined with perioperative chemotherapy [23, 24] while the role of biologics is largely unknown [25]. It has been known for 15 years that 'conversion chemotherapy' can augment the rate of liver resections and other local treatments $[26,27]$. In recent years, induction chemotherapy is often combined with therapeutic antibodies, yielding higher response rates than chemotherapy alone and acceptable survival outcomes [28, 29].

Nowadays, a variety of ablation and other local treatment modalities (including transarterial chemoembolization and selective internal radiotherapy) are available and are increasingly being used to treat visceral tumor dissemination to the liver and other organs. These physical methods that may improve outcome in cancer are interesting [30]; however, the evidence for physical treatment improving survival outcomes is still scarce. The only study that evaluated systematically the integration of local ablation techniques, especially radiofrequency ablation (RFA), in the management of metastatic colorectal cancer is the EORTC intergroup randomized study 40004 (CLOCC trial) [31]: This phase II study, originally started as a phase III design, randomly assigned 119 patients with non-resectable colorectal liver metastases to either systemic treatment $(\mathrm{n}=59)$ or systemic treatment plus RFA ( \pm resection) $(\mathrm{n}=60)$. The primary objective was a 30 -month OS rate of $>38 \%$ for the combined treatment group. The primary end point has been met, the 30 -month OS rate was $61.7 \%$ (95\% CI 48.2-73.9) for combined treatment. However, the 30-month OS for systemic treatment was 57.6\% (95\% CI 44.1-70.4), higher than anticipated. Median OS was 45.3 months for combined treatment and 40.5 months for systemic treatment $(\mathrm{p}=0.22)$. The PFS rate at 3 years for combined treatment was $27.6 \%$ compared with $10.6 \%$ for systemic treatment only (HR $0.63 ; 95 \%$ CI $0.42-0.95 ; \mathrm{p}=0.025)$. Median PFS was 16.8 months (95\% CI 11.7-22.1) and 9.9 months (95\% CI 9.3-13.7), respectively. The study met the primary end point on 30-month OS; however, the results in the control arm were in the same range. RFA plus systemic treatment resulted in significantly longer PFS. At present, the ultimate effect of RFA on OS remains uncertain. 


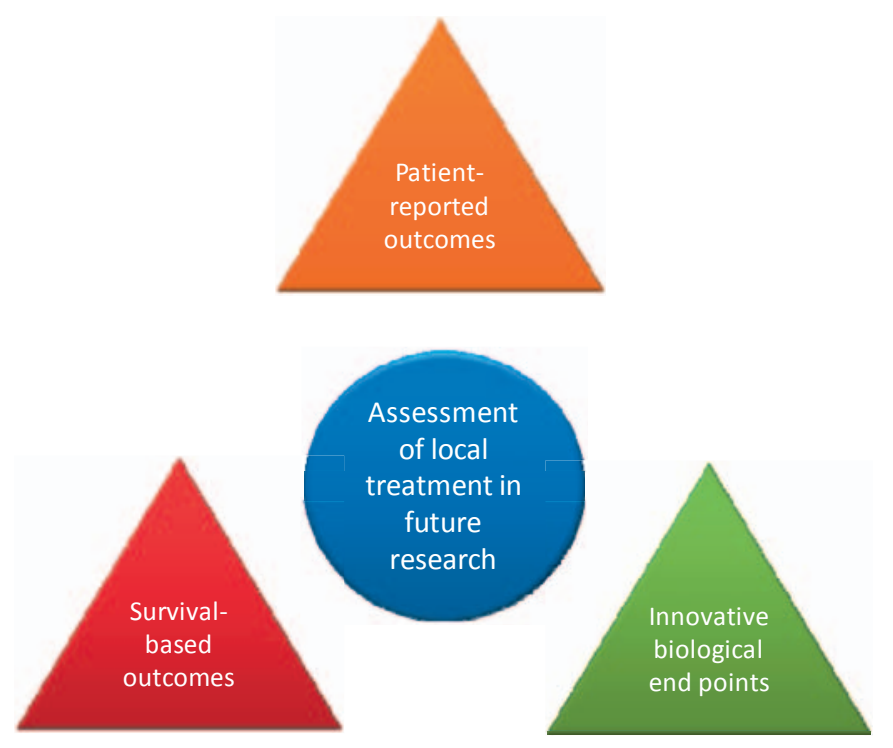

Fig. 3. Toward new outcome assessments for local therapies in advanced cancer.

\section{Experience from Gastrointestinal Stromal Tumors}

Another very interesting albeit completely different indication for local treatment in metastatic disease comes from gastrointestinal stromal tumors (GIST): Therapy with tyrosine kinase inhibitors (TKI) benefits over $80 \%$ of patients with advanced GIST, but most patients eventually develop drug resistance. The surgical approach that has been studied in GIST concerns development of focal resistance. Authors from New York investigated if resection of resistant clones following tumor shrinkage and control with TKI may improve outcome [32]: 40 patients with metastatic GIST were treated with TKI and then underwent surgical resection. Based on the growth of their tumors monitored by serial radiologic imaging, patients were categorized at the time of operation as having responsive disease, focal resistance (1 tumor growing), or multifocal resistance (more than 1 tumor growing). Patients were followed for a median of 15 months (range 6-46 months) after surgery. Initially, molecular therapy achieved stable disease or a partial response in all but 1 patient. Surgery was performed after a median of 15 months. After operation, the 20 patients with responsive disease had a 2-year PFS of $61 \%$ and a 2 -year OS of $100 \%$. In contrast, the 13 patients with focal resistance progressed after surgery at a median of 12 months, and 2 -year OS was $36 \%$. The 7 patients with multifocal resistance progressed postoperatively at a median of 3 months and had a 1-year OS of $36 \%$. In conclusion, selected patients with metastatic GIST, who have responsive disease or focal resistance to TKI therapy, may benefit from elective surgical resection. Surgery for patients with metastatic GIST, who have multifocal resistance, is generally not indicated.

In summary, in disease states where metastatic spread is confined to one compartment and where its extent can be controlled by local treatment, acceptable outcomes can be achieved. Locoregional treatment is often combined with systemic therapy. The goal of local treatment is to eradicate the disease as completely as possible. If this goal is not achieved, survival outcomes are no better than with conservative treatment alone. Another less frequent indication for local treatment is the ablation of focal resistant clones in disease states that have previously been successfully controlled with drug therapy. This indication is a valid option in GIST that develop focal resistance following medical treatment.

\section{Future End Points and Perspectives}

The longer patients with advanced cancer survive due to the increasing availability of active drugs, and the more technical innovations in the field of locoregional treatment we see, the more locoregional treatment is being used in oncology. How can we create evidence about the value of these treatment modalities? In general, current and future studies should adopt the following three approaches (fig. 3).

\section{Conventional Study End Points}

While a list of accepted study end points has been developed for cancer drug approval (table 1) [33], no accepted and generally applied selection of end points exists for locoregional treatment modalities. It could be called into question whether end points for drug treatment can be applied for the assessment of locoregional treatment efficacy. As locoregional treatment should always be a part of a multimodality treatment strategy, it will be much more demanding to test for the durable effect of one of the applied modalities. This is particularly true as the disease states in which locoregional treatments are applied tend to be heterogeneous. This renders it demanding to standardize or narrow down the study selection criteria. Experience teaches us that studies in which locoregional treatment is tested are difficult to conduct and slow to recruit patients [31]. Treatment outcomes can barely be foreseen due to the multiple influences from other treatment modalities and subsequent lines of treatment. Last but not least, difficulties may arise in obtaining funding for adequately powered clinical studies.

\section{Assessment of Biological Effects of Locoregional Treatment}

The use of local treatment in GIST may give direction to future approaches to locoregional treatment in general. Can the implementation of local ablation and cytoreduction treatment impact on the biology of the disease? As we progress in our understanding of tumor evolution and heterogeneity, it may be that the early integration of cytoreduction also leads to a reduction in cells from which drug resistance-defining alterations emerge, especially when patients have to be treated with anticancer drugs over a longer period 
Table 1. Clinical trial end points for the approval of cancer as recommended by the American Food and Drug Administration [33]

\begin{tabular}{|c|c|c|c|c|}
\hline End point & $\begin{array}{l}\text { Regulatory } \\
\text { evidence }\end{array}$ & Study design & Advantages & Disadvantages \\
\hline Overall survival & $\begin{array}{l}\text { clinical benefit } \\
\text { for regular } \\
\text { approval }\end{array}$ & $\begin{array}{l}\text { randomized studies essential; } \\
\text { blinding not essential }\end{array}$ & $\begin{array}{l}\text { universally accepted direct } \\
\text { measure of benefit; } \\
\text { easily measured; } \\
\text { precisely measured }\end{array}$ & $\begin{array}{l}\text { may involve larger studies; } \\
\text { may be affected by crossover } \\
\text { therapy and sequential therapy; } \\
\text { includes noncancer deaths }\end{array}$ \\
\hline $\begin{array}{l}\text { Symptom end points } \\
\text { (patient-reported } \\
\text { outcomes) }\end{array}$ & $\begin{array}{l}\text { clinical benefit } \\
\text { for regular } \\
\text { approval }\end{array}$ & randomized blinded studies & $\begin{array}{l}\text { patient perspective of direct } \\
\text { clinical benefit }\end{array}$ & $\begin{array}{l}\text { blinding is often difficult; } \\
\text { data are frequently missing or } \\
\text { incomplete; } \\
\text { clinical significance of small } \\
\text { changes is unknown; } \\
\text { multiple analyses; } \\
\text { lack of validated instruments }\end{array}$ \\
\hline Disease-free survival & $\begin{array}{l}\text { surrogate for } \\
\text { accelerated } \\
\text { approval or } \\
\text { regular } \\
\text { approval }^{\text {a }}\end{array}$ & $\begin{array}{l}\text { randomized studies essential; } \\
\text { blinding preferred; } \\
\text { blinded review recommended }\end{array}$ & $\begin{array}{l}\text { smaller sample size and shorter } \\
\text { follow-up necessary compared } \\
\text { with survival studies }\end{array}$ & $\begin{array}{l}\text { not statistically validated as } \\
\text { surrogate for survival in all settings; } \\
\text { not precisely measured; } \\
\text { subject to assessment bias, } \\
\text { particularly in open-label studies; } \\
\text { definitions vary among studies }\end{array}$ \\
\hline $\begin{array}{l}\text { Objective response } \\
\text { rate }\end{array}$ & $\begin{array}{l}\text { surrogate for } \\
\text { accelerated } \\
\text { approval or } \\
\text { regular } \\
\text { approval }^{\text {a }}\end{array}$ & $\begin{array}{l}\text { single-arm or randomized } \\
\text { studies can be used; } \\
\text { blinding preferred in } \\
\text { comparative studies; } \\
\text { blinded review recommended }\end{array}$ & $\begin{array}{l}\text { can be assessed in single-arm } \\
\text { studies; } \\
\text { assessed earlier and in smaller } \\
\text { studies compared with survival } \\
\text { studies; } \\
\text { effect attributable to drug, } \\
\text { not natural history }\end{array}$ & $\begin{array}{l}\text { not a direct measure of benefit; } \\
\text { not a comprehensive measure of } \\
\text { drug activity; } \\
\text { only a subset of patients who benefit }\end{array}$ \\
\hline Complete response & $\begin{array}{l}\text { surrogate for } \\
\text { accelerated } \\
\text { approval or } \\
\text { regular } \\
\text { approval }^{\text {a }}\end{array}$ & $\begin{array}{l}\text { single-arm or randomized } \\
\text { studies can be used; } \\
\text { blinding preferred in } \\
\text { comparative studies; } \\
\text { blinded review recommended }\end{array}$ & $\begin{array}{l}\text { can be assessed in single-arm } \\
\text { studies; } \\
\text { durable complete responses } \\
\text { can represent clinical benefit; } \\
\text { assessed earlier and in smaller } \\
\text { studies compared with survival } \\
\text { studies }\end{array}$ & $\begin{array}{l}\text { not a direct measure of benefit in } \\
\text { all cases; } \\
\text { not a comprehensive measure of } \\
\text { drug activity; } \\
\text { small subset of patients with benefit }\end{array}$ \\
\hline $\begin{array}{l}\text { Progression-free } \\
\text { survival (includes } \\
\text { all deaths) or time } \\
\text { to progression } \\
\text { (deaths before } \\
\text { progression } \\
\text { censored) }\end{array}$ & $\begin{array}{l}\text { surrogate for } \\
\text { accelerated } \\
\text { approval or } \\
\text { regular } \\
\text { approval }^{\text {a }}\end{array}$ & $\begin{array}{l}\text { randomized studies essential; } \\
\text { blinding preferred; } \\
\text { blinded review recommended }\end{array}$ & $\begin{array}{l}\text { smaller sample size and shorter } \\
\text { follow-up necessary compared } \\
\text { with survival studies; } \\
\text { measurement of stable disease } \\
\text { included; } \\
\text { not affected by crossover or } \\
\text { subsequent therapies; } \\
\text { generally based on objective } \\
\text { and quantitative assessment }\end{array}$ & $\begin{array}{l}\text { not statistically validated as } \\
\text { surrogate for survival in all settings; } \\
\text { not precisely measured; subject to } \\
\text { assessment bias particularly in } \\
\text { open-label studies; } \\
\text { definitions vary among studies; } \\
\text { frequent radiological or other } \\
\text { assessments; } \\
\text { involves balanced timing of } \\
\text { assessments among treatment arms }\end{array}$ \\
\hline
\end{tabular}

${ }^{a}$ Adequacy as a surrogate end point for accelerated approval or regular approval is highly dependent upon other factors such as effect size, effect duration, and benefits of other available therapy.

of time. In the area of solid tumor oncology, it is notoriously difficult to study these mechanisms as tumor material is often difficult to obtain and sequential sampling during treatment is obsolete in the majority of cases. However, nowadays, with the emerging techniques of plasma DNA investigation by different methodologies, the situation may change $[34,35]$. The ability to detect and quantify tumor mu- tations has proven effective in tracking tumor dynamics in real time as well as serving as a liquid biopsy that can be used for a variety of clinical and investigational applications not previously possible. It is now time to move forward and to design clinical studies assessing the effect of local treatment on tumor evolution and development of drug resistance by using liquid biopsy techniques. 


\section{Patient-Reported Outcomes}

In the vast majority of indications, local therapies in stage IV are used with palliative intent. The major goal of palliative treatment is to prolong survival, to control symptoms, and to maintain quality of life. It is more than reasonable to look at these achievements from a patient's perspective. Very recently, it was advocated in the New England Journal of Medicine that we should move toward 'patient-centered drug development' in oncology [36]. In another article, it was emphasized that assessing participant-centered outcome should be strengthened to improve clinical research in general [37]. Better symptom control, avoiding never-ending sequences of cytotoxic drug therapies, and delaying tumor progression at critical sites are effects achievable by implementing local ther- apies, which may have a major impact on patients' quality of life and satisfaction with care. Why not ask the patients about their perception of local treatment in advanced cancer? It is time to move into this direction. The palliative care research community has shown the right way in demonstrating that early integration of palliative care does not only prevent futile chemotherapy and prolong survival but also has a major impact on patient-centered quality of life, symptom control, and satisfaction with treatment $[38,39]$.

\section{Disclosure Statement}

The authors declare no conflicts of interest.

\section{References}

1 Sobin LH, Gospodarowicz MK, Wittekind C: TNM Classification of Malignant Tumours, ed 7. Oxford, Wiley-Blackwell, 2009.

2 Hellman S, Weichselbaum RR: Oligometastases. J Clin Oncol 1995;13:8-10.

>3 Rhim AD, Mirek ET, Aiello NM, Maitra A, Bailey JM, McAllister F, Reichert M, Beatty GL, Rustgi AK, Vonderheide RH, Leach SD, Stanger BZ: EMT and dissemination precede pancreatic tumor formation. Cell 2012;148:349-361.

4 Kalluri R, Weinberg RA: The basics of epithelialmesenchymal transition. J Clin Invest 2009;119: $1420-1428$.

5 Weichselbaum RR, Hellman S: Oligometastases revisited. Nat Rev Clin Oncol 2011;8:378-382.

6 Gerlinger M, Rowan AJ, Horswell S, et al: Intratumor heterogeneity and branched evolution revealed by multiregion sequencing. $\mathrm{N}$ Engl J Med 2012;366:883-892.

7 Aparicio S, Caldas C: The implications of clonal genome evolution for cancer medicine. N Engl J Med 2013;368:842-851.

8 Tannock IF: Removing the primary tumor after the cancer has spread. N Engl J Med 2001;345:1699-1700.

-9 Flanigan RS, Salmon SE, Blumenstein BA, Bearman SI, Roy V, McGrath PC, Caton JR Jr, Munshi N, Crawford ED: Nephrectomy followed by interferon alfa- $2 b$ compared with interferon alpha- $2 b$ alone for metastatic renal-cell cancer. $\mathrm{N}$ Engl J Med 2001;345:1655-1659.

10 Mickisch GHJ, Garin A, van Poppel H, de Prijck L, Sylvester R; European Organisation for Research and Treatment of Cancer (EORTC) Genitourinary Group: Radical nephrectomy plus interferon-alfabased immunotherapy compared with interferon alfa alone in metastatic renal-cell carcinoma: a randomised trial. Lancet 2001;358:966-970.

11 Cook AD, Single R, McCahill LE: Surgical resection of primary tumors in patients who present with stage IV colorectal cancer: an analysis of surveillance, epidemiology, and end results data, 1988 to 2000. Ann Surgical Oncol 2005;12:637-645.

$\checkmark 12$ Venderbosch S, de Wilt JH, Teerenstra S, Loosveld OJ, van Bochove A, Sinnige HA, Creemers GJ, Tesselaar ME, Mol L, Punt CJ, Koopman M: Prognostic value of resection of primary tumor in patients with stage IV colorectal cancer: retrospective analysis of two randomized studies and a review of the literature. Ann Surg Oncol 2011;18:3252-3260.
13 Ferrand F, Malka D, Bouuredjem A, Allonier C, Bouché O, Louafi S, Boige V, Mousseau M, Raoul JL, Bedenne L, Leduc B, Deguiral P, Faron M, Pignon JP, Ducreux M: Impact of primary tumour resection on survival of patients with colorectal cancer and synchronous metastases treated by chemotherapy: results from the multicenter, randomised trial Fédération Francophone de Cancérologie Digestive 9601. Eur J Cancer 2013;49:90-97.

14 Rahbari NN, Lordick F, Fink C, Bork U, Stange A, Jäger D, Luntz SP, Englert S, Rossion I, Koch M, Büchler MW, Kieser M, Weitz J; SYNCHRONOUS trial group: Resection of the primary tumour versus no resection prior to systemic therapy in patients with colon cancer and synchronous unresectable metastases (UICC stage IV): SYNCHRONOUS - a randomised controlled multicentre trial (ISRCTN30964555). BMC Cancer 2012;12:142.

15 McCartney A: The tip of the iceberg. BMJ 1994; 309:1025.

16 Schorge JO, Bradford LS, del Carmen MG: Primary cytoreductive surgery for advanced ovarian cancer: is it the past, present, or future? Clin Adv Hematol Oncol 2011;9:912-918.

17 Morrison J, Haldar K, Kehoe S, Lawrie TA: Chemotherapy versus surgery for initial treatment in advanced ovarian epithelial cancer. Cochrane Database Syst Rev 2012;8:CD005343.

18 Vergote I, Amant F, Kristensen G, Ehlen T, Reed NS, Casado A: Primary surgery or neoadjuvant chemotherapy followed by interval debulking surgery in advanced ovarian cancer. Eur J Cancer; 47(suppl 3):S88-92.

19 Armstrong DK, Bundy B, Wenzel L, Huang HQ, Baergen R, Lele S, Copeland LJ, Walker JL, Burger RA; Gynecologic Oncology Group: Intraperitoneal cisplatin and paclitaxel in ovarian cancer. N Engl J Med 2006;354:34-43.

20 Sugarbaker PH: Parietal peritonectomy. Ann Surg Oncol 2012;19:1250.

21 Koch M, Weitz J, Kienle P, Benner A, Willeke F, Lehnert T, Herfarth C, von Knebel Doeberitz M: Comparative analysis of tumor cell dissemination in mesenteric, central, and peripheral venous blood in patients with colorectal cancer. Arch Surg 2001; 136:85-89.
22 Adam R, De Gramont A, Figueras J, Guthrie A, Kokudo N, Kunstlinger F, Loyer E, Poston G, Rougier P, Rubbia-Brandt L, Sobrero A, Tabernero J, Teh C, Van Cutsem E; Jean-Nicolas Vauthey of the EGOSLIM (Expert Group on OncoSurgery management of Liver Metastases) group: The oncosurgery approach to managing liver metastases from colorectal cancer: a multidisciplinary international consensus. Oncologist 2012;17:1225-1239.

23 Lordick F, Knödler M, Hacker U, Bartels M: Neoadjuvant chemotherapy or primary surgery for colorectal liver metastases. Pro adjuvant chemotherapy. Chirurg 2014;85:11-16.

24 Nordlinger B, Sorbye H, Glimelius B, Poston GJ, Schlag PM, Rougier P, Bechstein WO, Primrose JN, Walpole ET, Finch-Jones M, Jaeck D, Mirza D, Parks RW, Mauer M, Tanis E, Van Cutsem E, Scheithauer W, Gruenberger T; EORTC GastroIntestinal Tract Cancer Group; Cancer Research UK; Arbeitsgruppe Lebermetastasen und -tumoren in der Chirurgischen Arbeitsgemeinschaft Onkologie (ALM-CAO); Australasian Gastro-Intestinal Trials Group (AGITG); Fédération Francophone de Cancérologie Digestive (FFCD): Perioperative FOLFOX4 chemotherapy and surgery versus surgery alone for resectable liver metastases from colorectal cancer (EORTC 40983): long-term results of a randomised, controlled, phase III trial. Lancet Oncol 2013;14:1208-1215.

25 Nordlinger B, Adam R, Arnold D, Zalcberg JR, Gruenberger T: The role of biological agents in the resection of colorectal liver metastases. Clin Oncol (R Coll Radiol) 2012;24:432-442.

26 Giacchetti S, Itzhaki M, Gruia G, Adam R, Zidani R, Kunstlinger F, Brienza S, Alafaci E, BertheaultCvitkovic F, Jasmin C, Reynes M, Bismuth H, Misset JL, Lévi F: Long-term survival of patients with unresectable colorectal cancer liver metastases following infusional chemotherapy with 5-fluorouracil, leucovorin, oxaliplatin and surgery. Ann Oncol 1999;10:663-669.

27 Adam R, Delvart V, Pascal G, Valeanu A, Castaing D, Azoulay D, Giacchetti S, Paule B, Kunstlinger F, Ghémard O, Levi F, Bismuth H: Rescue surgery for unresectable colorectal liver metastases downstaged by chemotherapy: a model to predict long-term survival. Ann Surg 2004;240:644-657. 
-28 Ye LC, Liu TS, Ren L, Wei Y, Zhu DX, Zai SY, Ye QH, Yu Y, Xu B, Qin XY, Xu J: Randomized controlled trial of cetuximab plus chemotherapy for patients with KRAS wild-type unresectable colorectal liver-limited metastases. J Clin Oncol 2013;31:1931-1938.

-29 Folprecht G, Gruenberger T, Bechstein W, Raab HR, Weitz J, Lordick F, Hartmann JT, Stoehlmacher-Williams J, Lang H, Trarbach T, Liersch T, Ockert D, Jaeger D, Steger U, Suedhoff T, Rentsch A, Köhne CH: Survival of patients with initially unresectable colorectal liver metastases treated with FOLFOX/cetuximab or FOLFIRI/cetuximab in a multidisciplinary concept (CELIM-study). Ann Oncol 2014;25:1018-1025.

30 Melzer A, Cochran S, Prentice P, MacDonald MP Wang Z, Cuschieri A: The importance of physics to progress in medical treatment. Lancet 2012;379: 1534-1543.
1 Ruers T, Punt C, Van Coevorden F, Pierie JP, Borel-Rinkes I, Ledermann JA, Poston G, Bechstein W, Lentz MA, Mauer M, Van Cutsem E, Lutz MP, Nordlinger B; EORTC Gastro-Intestinal Tract Cancer Group, Arbeitsgruppe Lebermetastasen und -tumoren in der Chirurgischen Arbeitsgemeinschaft Onkologie (ALM-CAO) and the National Cancer Research Institute Colorectal Clinical Study Group (NCRI CCSG): Radiofrequency ablation combined with systemic treatment versus systemic treatment alone in patients with non-resectable colorectal liver metastases: a randomized EORTC Intergroup phase II study (EORTC 40004). Ann Oncol 2012;23:2619-2626.

32 DeMatteo RP, Maki RG, Singer S, Gonen M, Brennan MF, Antonescu CR: Results of tyrosine kinase inhibitor therapy followed by surgical resection for metastatic gastrointestinal stromal tumor. Ann Surg 2007;245:347-352.

33 Federal Drug Administration: Clinical Trial Endpoints for the Approval of Cancer Drugs and Biologics. Clinical Trial Endpoints for the Approval of Cancer. www.fda.gov/default.htm.
4 Bettegowda C, Sausen M, Leary RJ, et al: Detection of circulating tumor DNA in early- and latestage human malignancies. Sci Transl Med 2014;6 $224 \mathrm{ra} 24$.

35 Diaz LA Jr, Bardelli A: Liquid biopsies: genotyping circulating tumor DNA. J Clin Oncol 2014;32: 579-586.

36 Basch E: Toward patient-centered drug development in oncology. N Engl J Med 2013;369:397-400.

37 Kost RG, Lee LM, Yessis J, Wesley RA, Henderson DK, Coller BS: Assessing participant-centered outcomes to improve clinical research. N Engl J Med 2013;369:2179-2181.

38 Temel JS, Greer JA, Muzikansky A, Gallagher ER, Admane S, Jackson VA, Dahlin CM, Blinderman CD, Jacobsen J, Pirl WF, Billings JA, Lynch TJ: Early palliative care for patients with metastatic non-small-cell lung cancer. N Engl J Med 2010;363:733-742.

39 Zimmermann C, Swami N, Krzyzanowska M, Hannon B, Leighl N, Oza A, Moore M, Rydall A, Rodin G, Tannock I, Donner A, Lo C: Early palliative care for patients with advanced cancer: a cluster-randomised controlled trial. Lancet 2014;383: 1721-1730. 